\title{
CLaCS Guiado pela Realidade Aumentada
}

\author{
Miyake K. ${ }^{1}$ \\ ${ }^{1}$ São Paulo - SP. \\ E-mail: kasuomiyake@gmail.com
}

Miyake, K. 2013. CLaCS Guiado pela Realidade Aumentada, p.33. In: Bastos, Francisco Reis. Anais do V Simpósio Internacional de Flebologia [Blucher Medical Proceedings n.1 v.1]. São Paulo: Blucher, 2014

http://dx.doi.org/10.5151/medpro-flebo-SIF_14
CLaCS é um acrônimo de "Cryo-Laser and Cryo Sclerotherapy". Essa técnica visa conseguir uma técnica de escleroterapia que seja segura (livre de embolia, ulceração venosa e anafilaxia), eficiente, duradoura, confortável e que possa diminuir o número de sessões para se atingir a melhora estética visível na documentação fotográfica pré e pós tratamento. Nossa equipe iniciou a combinação de Luz com Glicose 75\% em 1995. Desde então, os equipamentos emissores de luz (luz intensa pulsada ou laser) vieram evoluindo e aumentando o poder de fototermólise seletiva. O termo "Cryo" se refere a um aparelho que emite ar gelado a temperaturas que chegam a $-20^{\circ} \mathrm{C}$. O objetivo do uso desse aparelho combinado com o laser e a escleroterapia é multiplo: refrigerar a pele para proteger a pele durante os disparos de laser, diminuir em $15-30^{\circ} \mathrm{C}$ a temperatura da pele diminuindo a sensação dolorosa durante a técnica do laser e da escleroterapia por injeção, e ainda resfriar a telangiectasia, a agulha e consequentemente o líquido esclerosante para obter os benefícios provados pela técnica da crioescleroterapia demonstradas na Tese de Doutorado do Dr Francischelli. Realidade Aumentada (RA) é a mistura do mundo real com a imagem digital. Há diferentes tipos de RA, sendo uma das mais interessantes a "espacial" onde o usuário não precisa de óculos ou um anteparo de vidro ou monitor entre seus olhos e o objeto a ser analizado com RA. Em 2005, foi criado o primeiro protótipo de RA espacial em medicina, o VeinViewer. Nessa época, propusemos ao cientista um estudo em varizes já que o aparelho estava sendo desenvolvido para auxílio em punções venosas apenas. Desde então, estudamos e utilizamos RA na fleboestética. De 2007 a 2009 concluimos que o CLaCS guiado pela RA conseguiu diminuir $86 \%$ a necessidade de cirurgia de colaterais em nosso serviço. Nessa aula demonstraremos a técnica e nossa experiência ao longo desses últimos 8 anos.

Palavras-chave: CLaCs, laser, varizes, tratamento de varizes. 